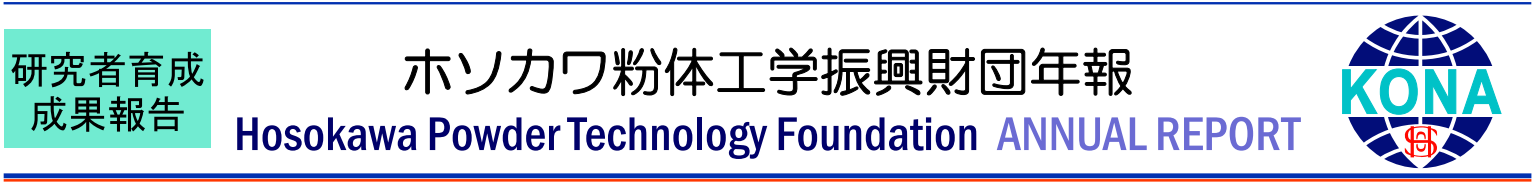

\title{
粒界固相焼結を用いた常圧熱処理による 炭化ケイ素焼結体合成プロセス開発に関する研究 \\ Study on Synthesis Process of Silicon Carbide Sintered Body by Pressure-less Heat Treatment Using Grain Boundary Solid-phase Sintering
}

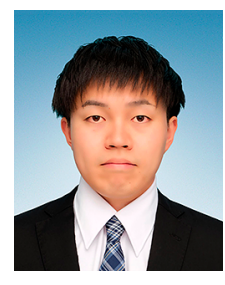

薄川 隆太郎

\begin{abstract}
援助対象者 Scholarship Student: 薄川 隆太郎 Ryutaro USUKAWA E-mail: f118701@ed.socu.ac.jp

$\begin{array}{ll}\text { 研究指導者 Academic Leader: } & \text { 石川 敏弘 Toshihiro ISHIKAWA } \\ & \text { 教授, Professor } \\ & \text { E-mail: ishikawa@rs.socu.ac.jp }\end{array}$
\end{abstract}

山陽小野田市立山口東京理科大学大学院工学研究科 博士課程後期 2 年 Graduate school of Engineering, Sanyo-Onoda City University, PhD Student (D2)

成 果 の 概 要

\section{1. 緒言}

炭化ケイ素は共有結合性が強く難焼結材料と して知られており，焼結助剤の添加なしでは緻 密な焼結体を得ることが困難である（Khodaei M. et al, 2019)。これまで, 炭化ケイ素焼結体 の作製方法として，ホウ素と炭素を焼結助剤と した固相焼結法が報告されているが，焼結温度 が $2000^{\circ} \mathrm{C}$ を超える上, 破壊勒性值が低い問題 点がある (Prochazka S. and Scanlan R.M., 1975). 一方, $\mathrm{Al}_{2} \mathrm{O}_{3}$ などを用いた液相焼結法は, $\sim 1900^{\circ} \mathrm{C}$ の焼結温度で高い破壊勒性值を得るこ とができるが，焼結助剤が粒界第二相を形成す るため, 高温特性が焼結助剂の種類や添加量 に強く依存する（Rasouli S. and Taheri-Nassaj E., 2010)。また, いずれの方法も，炭化ケイ素粉 末と焼結助剂を物理的に混合するため均一混合 が困難である.
当研究室ではこれまでに, 有機ケイ素ポリ マーに焼結助剂としてアルミニウムが均一固溶 した前駆体を用いて，粒界第二相を形成しない 緻密な結晶質炭化ケイ素繊維を粒界固相焼結に より合成することに成功している（Ishikawa T., et al., 1998)。本研究では, 同様に焼結助剂とし てアルミニウムを採用し, 炭化ケイ素粉末の前 駆体段階で含有させることで，元素レベルで均 一混合し, 繊維内で起きた粒界固相焼結現象を 用いて，粒界第二相を形成しない焼結体を作製 することを最終目的する，本報告では，前段階 として原料であるアルミニウムが含有した炭化 ケイ素粉末の合成を目的とする。

\section{2. 実験方法}

アルミニウムを含有した炭化ケイ素粉末 $(\mathrm{Al}-$ $\mathrm{SiC} ）$ は，ヒドロキシ化 TEOS，硝酸アルミニ ウム九水和物, クエン酸を原料とするクエン酸 錯体重合法により合成した。なお，アルミニウ 
ムの添加量は, $\mathrm{SiC} に$ 対する固溶限界以下であ る $0.5 \mathrm{wt} \%$ とした。また，ヒドロキシ化 TEOS を $1 \mathrm{~mol}$ で固定し, 添加するクエン酸量を変動 させることで，前駆体粉末中における $\mathrm{SiO}_{2}$ と Cの割合を制御し，さらに $\mathrm{Al}-\mathrm{SiC}$ 中での残存 炭素量の調整を試みた。構造解析は TG-DTA, XRD, Ramanにより行い, 形態観察および元 素分析は STEM で行った。

\section{3. 結果と考察}

前駆体粉末中に含まれる炭素量をTG-DTA により定量した（図 1). SiC を合成する化学反 応 $\left(\mathrm{SiO}_{2}+3 \mathrm{C} \rightarrow \mathrm{SiC}+2 \mathrm{CO}\right)$ が化学量論的に進 行するのは, 理論上 $\mathrm{C} / \mathrm{SiO}_{2}$ が 3.0 の時であり, クエン酸添加量が約 $2 \mathrm{~mol}$ の時に $\mathrm{C} / \mathrm{SiO}_{2}$ が 3.0 付近になっていることが分かった。

次に, クエン酸添加量 1.6 2.4 mol で合成し た時の結晶構造をXRDにより確認した（図 2). いずれの場合においても, 目的物である $\beta-\mathrm{SiC}$

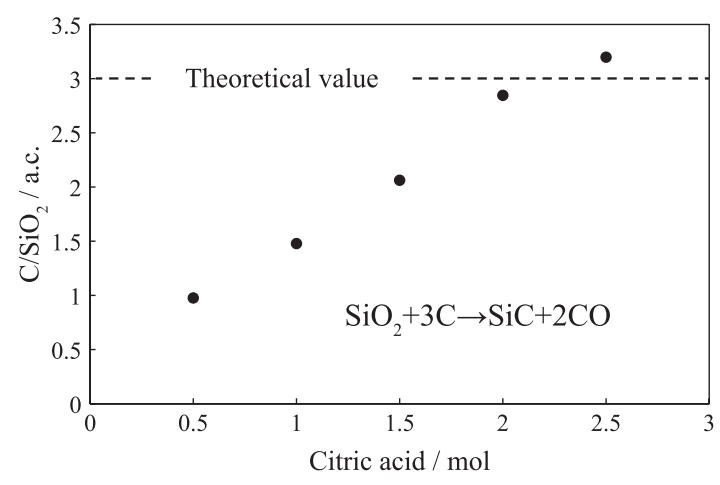

Fig. $1 \mathrm{C} / \mathrm{SiO}_{2}$ ratio of $\mathrm{Al}-\mathrm{SiC}$ precursor.

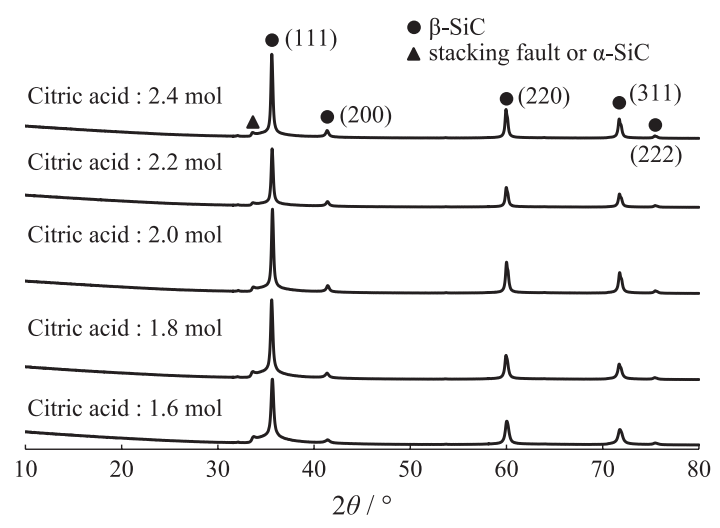

Fig. 2 XRD patterns of Al-SiC powder.
が得られていることが分かった。また，焼結助 剤として添加したアルミニウムに由来した結晶 構造が見られないことから，アルミニウムが炭 化ケイ素に対して固溶していると示唆される. 一方, $33.6^{\circ}$ 付近にあるピークに関しては, a-SiC と $\mathrm{SiC}$ の積層のずれによって生じる積層 欠陥との可能性があるが, XRD では両者を明 確に区別することは出来なかった.

そこで, ラマンスペクトルを測定した（図 3). $\beta-\mathrm{SiC}$ に由来したバンドは認められたが， $\alpha-\mathrm{SiC}$ に由来したバンドは認められてなかった。さら に, $\beta-\mathrm{SiC}$ のバンドをみると, 据の広がりや非 対称性が生じている。これは積層欠陥が生じた 時に見られる特徵と一致しているため, XRD

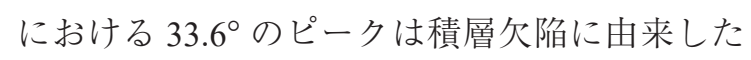
ものと考えられる。また， $1000 \mathrm{~cm}^{-1}$ 以上をみ るとクエン酸添加 $2.0 \mathrm{~mol}$ 以上で合成した試料 では炭素に由来したバンドが存在していること が分かる。したがって, クエン酸添加 $2.0 \mathrm{~mol}$ 以上では得られた炭化ケイ素粉末に残存炭素が 含まれていると推定される。

残存炭素量を TG-DTAにて定量した（図 4). クエン酸添加量 $1.8 \mathrm{~mol}$ 以下で合成した場合, $\mathrm{C} / \mathrm{Si}$ はほほ 1.00 と化学量論組成の炭化ケイ素 粉末が得られていることが分かる。一方, クエ ン酸添加量 $2.0 \mathrm{~mol}$ 以上で合成した添加量の増 大に伴い, 残存炭素量も増大していることが分 かる、これは, ラマンスペクトルの結果と一致 している. $\mathrm{C} / \mathrm{SiO}_{2}$ が 3.0 以下の領域で残留炭素

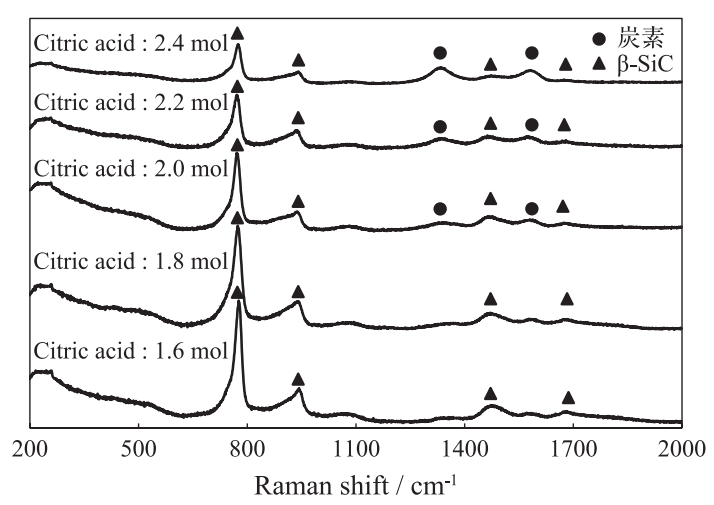

Fig. 3 Raman spectra of Al-SiC powder. 


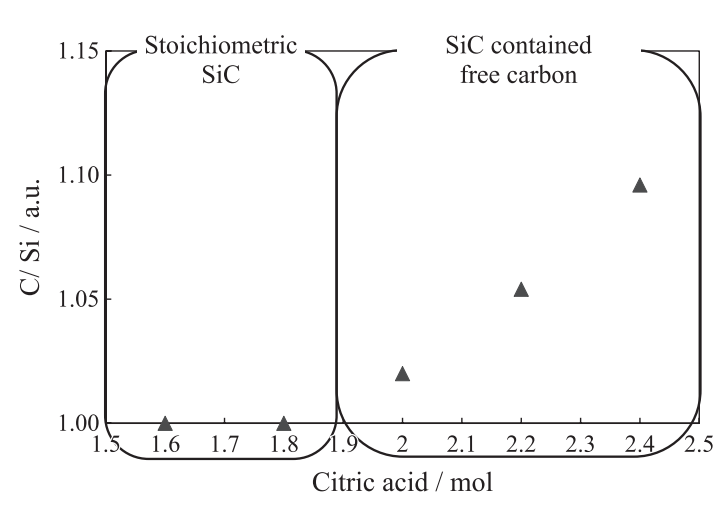

Fig. $4 \mathrm{C} / \mathrm{Si}$ ratio of $\mathrm{Al}-\mathrm{SiC}$ precursor.
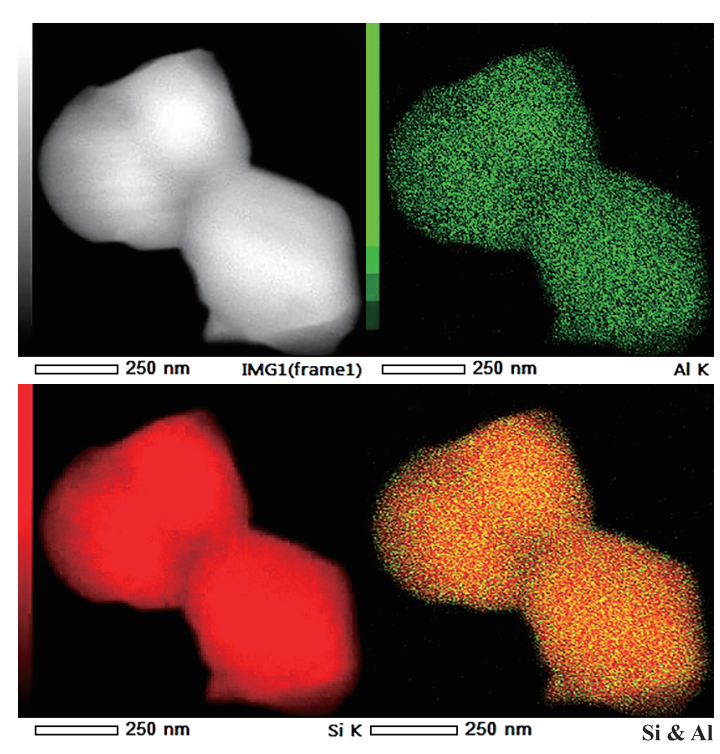

Fig. 5 STEM images and EDS mapping of Al-SiC precursor.

が生じているのは, $1150^{\circ} \mathrm{C}$ から始まる $\mathrm{SiO} の$ 蒸発によって，系内での組成ずれが生じたため

\section{外部発表成果}

\section{口頭・ポスター発表}

1. 薄川隆太郎, “新規な $\mathrm{SiC}$ 固相焼結体の製造 技術と物性評価”第 7 回 NIMS 構造材料研 究拠点シンポジウム（Tsukuba, Aug. 30).

2. 薄川隆太郎, “焼結助剂成分を含有した新規
であると示唆される。

最後にアルミニウムの分散状態をSTEMの EDS マッピングにより確認した（図 5)。アル ミニウムはケイ素に対して偏在することなく, 均一に分散していることが分かる．XRDの結 果と統合的に判断すると, 炭化ケイ素の結晶構 造を壊さずに, 格子内に元素レベルでアルミニ ウム原子が固溶していると推定される。

今後，己れまでに検討した各条件で合成した $\mathrm{Al}-\mathrm{SiC}$ 粉末を用いて, 焼結体の作製および物 性評価に着手する予定である。

\section{参考文献}

Ishikawa T., Kohtoku Y., Kumagawa K., Yamamura T., Nagasawa T., High-strength alkali-resistant sintered SiC fibre stable to $2,200^{\circ} \mathrm{C}$, Nature, 391 (1998) $773-$ 775. https://doi.org/10.1038/35820

Khodaei M., Yaghobizadeh O., Naghavi Alhosseini S.H., Esmaeeli S., Mousavi S.R., The effect of oxide, carbide, nitride and boride additives on properties of pressureless sintered SiC: A review, Journal of the European Ceramic Society, 39 (2019) 2215-2231.

https://doi.org/10.1016/j.jeurceramsoc.2019.02.042

Prochazka S., Scanlan R.M., Effect of boron and carbon on sintering of SIC, Journal of the American Ceramic Society, 58 (1975) 72-72. https://doi.org/10.1111/j.1151-2916.1975.tb18990.x

Rasouli S., Taheri-Nassaj E., In situ preparation of $\mathrm{Al}_{2} \mathrm{O}_{3}-\mathrm{SiC}$ nanocomposites via sol-gel method followed by pressureless sintering, Journal of Alloys and Compounds, 496 (2010) 678-682.

https://doi.org/10.1016/j.jallcom.2010.02.167

炭化ケイ素粉末の合成法”, SATテクノロ ジー・ショーケース 2020（Tsukuba, Jan. 24, 2020) P-10.

3. 薄川隆太郎, 石川敏弘, “焼結助剂成分を均 一に含有した炭化ケイ素粉末の合成”, 日本 セラミックス協会 2020 年年会（Tokyo, March 18-20, 2020) 1P200. 